\title{
Time Factor Influencing Technology Integration in Social Studies Teaching in Jordanian School
}

\author{
Mohammad Abed Latif Mohammad Smadi ${ }^{1 *}$ (), Arumugam Raman ${ }^{1}$ (C)
}

${ }^{1}$ School of Education and Modern Languages (SEML), University Utara Malaysia, MALAYSIA

*Corresponding Author: moh.smadi1987@yahoo.com

Citation: Smadi, M. A. L. M., \& Raman, A. (2020). Time Factor Influencing Technology Integration in Social Studies Teaching in Jordanian School. European Journal of Interactive Multimedia and Education, 1(1), e02004. https://doi.org/10.30935/ejimed/8351

\begin{abstract}
The purpose of this qualitative research study was to examine the time factor influencing technology integration in social studies teaching in a Jordanian school. The case study method was chosen because the research questions sought to explore time factor influencing technology integration in teaching. In Jordan, little research qualitative empirical research has investigated the level of the time of technology has been carried out for educational purposes. Therefore, this paper intends to identify the importance of the time factor of teachers in technology integration in teaching. These data were analysed using a thematic analysis approach, semi-structured interview interviews and observation were used as instruments to collect data. Five social studies teachers participated in this study. Findings showed that all of the teachers have mentioned that the time was one of the most important factors that affected the technology integration in their teaching. Where most of the responses indicated that, the time was a major obstacle in front of their technology integration. Furthermore, I found out through my classroom observations that the time was an obstacle for all teachers.
\end{abstract}

Keywords: time, influence, technology, integration, teaching, social studies

Received: 17 May $2020 \bullet$ Accepted: 13 Jun. 2020

\section{INTRODUCTION}

Nowadays, the technology is a necessity within the learning environment for teaching the 21st century skills (Steele, 2017). Technology integration is needed in today's classrooms to facilitate an increased student's achievement in thinking critically, creativity, problem solving, collaboration, and communication (Strange, 2018). It is very clear that teachers play a main role in technology integration.

The teachers are faced with the challenging task of not only learning how to use technology, but how to effectively technology integration in their teaching (Aldhafeeri, Palaiologou, \& Folorunsho, 2016; Yusop, 2015).

In the similar context, there are certain factors that influence teachers' integration of technology: lack of training, lack of time, inadequate skills or knowledge (Vatanartiran \& Karadeniz, 2015). AlMulhim (2014) found five important barriers to technology integration in teaching that are teachers': lack of confidence, teachers' attitudes and beliefs, lack of skills and knowledge and lack of time. All these factors are essential to encourage teachers to integrate technology in their teaching. According to Strange (2018), time is yet another barrier to teacher integration of technology in the classrooms.

According to Bandyopadhyay (2013), the absence of the research into above factors in developing countries is conspicuous. This is a critical gap that warrants greater understanding of whether these same factors affect technology integration. Such a study is integral to unfolding factors that either hinder or assist teachers in their ability to introduce and integrating technology in classrooms. Also, Ames (2017) indicated that research is still needed to identify factors that help or hinder technology integration in classrooms. The knowledge of these factors is essential for encouraging teachers to introduce effective technology into their area of speciality within their working places $(\mathrm{Hu}$ \& Garimella, 2014).

This absence constitutes a critical knowledge gap that warrants a greater understanding of what affects the integration of technology in the classroom in developing countries, for example, Jordan.

In recent years, Jordan has paid increased attention to integrating technology into its K-12 curriculum, which has been made clear through the 2018-2022 Ministry of Education strategic plan (Jordanian Ministry of Education (JMoE), 2019). Many developing countries like Jordan have invested a large amount of money in integrating technology in the field of education by providing a teacher with good opportunities to use of technology into develop their skills and knowledge related to the technology integration (Al-Zaidiyeen, Mei, \& Fook, 2010).

In this context, research is required to determine where this integration stands and what policymakers and interested stakeholders can do to speed the process. Therefore, this current study is aimed at an in-depth exploration the time factor influencing technology integration 
in Jordanian classrooms more in-depth. The current study differs from other studies conducted in Jordan. The research that has conducted so far have focused on the quantitative data collection methodology, such as surveys (Al-Ghzo, 2018; Al-Zaidiyeen, 2015; Albataineh, 2014). Thus, this research fills the methodological gap.

The purpose of this qualitative research study was to examine the influence of time factor on the level of technology integration by teachers in a Jordanian-school. The case study method was chosen because the research questions sought to identify specific aspects of the time factor that influencing technology integration in classrooms. This case study used five six grade teachers of social studies from the five different schools in north of Jordan.

Two research questions guided this study, which were:

Q1: Do you have enough time to technology integration into your teaching?

Q2: Do you see that the time is a problem for you when technology integration is included in your teaching?

\section{LITERATURE REVIEW}

Wide varieties of factors have strong direct and indirect effects on successful technology integration. The literature examined a wide variety of factors, including teacher variables (e.g. level of education, teaching experience, teachers' knowledge and skills), school variables (e.g. level of technology support, access to technology and time (Beeson, 2013). It is important to consider factors that encourage teachers to initiate a change in order to incorporate emerging technologies into their instruction (Winterhalder, 2017).

The time factor is one of the most factors that influencing in technology integration in teaching (Kopcha, 2010). According to Hew and Brush (2007), teachers need time to preview websites and locate information for lessons. Teachers have indicated concerns as to the lack of time to plan lessons that integrate technology. As mention Kopcha (2010) that teachers need time to plan lessons that integrate technology and time to learn the hardware and software.

Technology integration requires time to burgeon and become part of a teacher's repertoire of instructional approaches. To increase teachers' integration of technology in the classrooms, there must be an intentional focus on providing time to plan for and practice integrating technology in the classroom (Beaudry, 2011). According to Nixon (2013) Time also supports successful integration of technology into classrooms. Teachers also need time to technology integrating in their teaching (Strange, 2018).

Some research has shown there has often been insufficient time during the school day to learn integration of technology into classrooms. (Bauland, 2012; Humble-Thaden, 2012). According to Strange (2018), teachers, generally, will not integrate technology on a regular basis without adequate time to prepare, practice, and share experiences. Lack of time to plan is negatively impacts technology integration in the classroom.

According to Winterhalder (2017), there are many Reasons that inhibit technology integration in teaching, such things as the lack of experience, lack of support for using technology and lack of time given to integrate technology into teachings. Moreover, teachers face challenges that may impede the process of both implementing and integrating technologies. These challenges can often prohibit teachers from using technologies in their teachings such as: lack of time and lack of technological knowledge and skill (Winterhalder, 2017).

In Jordan, the research on the integration of technology have focused on quantitative methods (Abuhmaid, 2008; Al-Bataineh, 2015; Al-Ruz \& Khasawneh, 2011; Al-Zaidiyeen, 2015). In this regard, AlBataineh (2014) recommended that future research using qualitative methods like interviews and observations should be conducted to gain more in-depth information. It could enrich the field and create a better understanding of technology integration in Jordan.

The current study addresses this call, using a qualitative research design (interview and observation) to fill this methodological gap. As the literature review revealed, very little research has been conducted on the technology integration in Jordanian schools. Thus, a need exists to conduct more research on time factor influencing the technology integration in Jordanian schools, particularly in "soft sciences" like social studies.

\section{METHOD}

The qualitative research design for this study was a case study, which utilised five teachers from five Jordanian schools. Data collection for this study involved face-to-face interviews and observations. The participants in this study used many of technological means such as, computer and data show, phone smart and several technological sources.

This study followed a set of procedures or processes, which was a follows:

A purposive sampling technique was used as recommended by other scholars for exploratory studies (i.e., Creswell, 2014, 2012, 2009; Patton, 2002; Sekaran, 2013). This study used purposeful sampling to optain an in-depth understanding of time factor influencing technology integration in social studies teaching in Jordanian school. Sekaran (2013) stated qualitative studies they can be conducted with a small number of individuals or organisations sample size.

The sample was limited to five schools in north, Jordan. One teacher from each school was used a formal letter sent to the school's managers requesting permission to conduct a study in their school. In this study, the interview was the main study method supplemented with classrooms observation. This research was based on a semi-structured interview with open-ended questions focusing on time factor influencing technology integration in social studies teaching. The interviews lasted from 50 to 70 minutes with each teacher. In addition, five observation session, that lasted from 40 to 45 minutes was conducted with each teacher.

This study used thematic analyses techniques to analyse the collected data. The data were analysed inductively, built from particulars to general themes (Creswell, 2007). Thematic analysis permits the provision of interpretations to data and helps in establishing a clear and systematic method of data analyses without threatening the depth and quality of that analysis. 


\section{FINDINGS}

\section{Research Questions}

The purpose of this qualitative research study was to explore time factor influencing technology integration in social studies teaching in Jordanian school. The case study method was chosen because the research questions sought to identify specific time factor influencing technology integration in classrooms.

As to the concerning, the amount of time needed for technology integration in teaching. There is two research questions guided the study, which were the following:

Q1: Do you have enough time to technology integration into your teaching?

Q2: Do you see that the time is a problem for you when technology integration is included in your teaching?

The objective of employing this question was to explore whether time was the factor that influenced the integration of technology in teaching. Where it was time to look at three main dimensions; lecture time, time available during the day and the period covered by the semester comparative with topics for material.

\section{Characteristics of the Participants}

The characteristics of the participants of the study are shown in Table 1.

Table 1. Characteristics of the Participants

\begin{tabular}{ccccc}
\hline Pseudonym & School & Gender & Age & Years of Experience \\
\hline F & 1 & F & 35 & 10 \\
\hline R & 2 & F & 41 & 12 \\
\hline M & 3 & M & 30 & 5 \\
\hline K & 4 & M & 37 & 7 \\
\hline D & 5 & F & 37 & 9
\end{tabular}

Interviews

The answers teachers have around the classrooms time was not enough, Also, different subjects within the same course. In addition, technology integration process that requires processing tools and resources to ensure its effectiveness and suitability for using it. All these issues needed more time for the teacher in the process of preparing. In addition, the subject of lesson sometimes requires the use of many technological means to deliver information properly for students. So, that the teachers needed to many time to be able technology integration in classrooms.

The responses of teachers were as follows:

Teacher F said, "one of the main obstacles to the integration of technology was time available for the classrooms". Especially, that the class time did not exceed 45 minutes only. In addition, "sometimes I needed two or three periods to cover the full topic".

There was another problem related to the time allocated to some of the topics within the curriculum. Five observed inside classrooms for many teachers showed that the teachers could not cover the subjects adequately.

According to teacher $\mathrm{D}$, she always suffered from the lack of time to teach her students and the time was the most important element should be exploited in the classroom. As she mentioned that, she took some of the time of her colleagues to be able to implement some of the lessons. This confirmed the weakness of the curriculum with regard to the allocation of adequate time to implement lessons in classrooms. Thus, that led to a weakness or failure to achieve the educational goals.

Teacher K said, "The time is one of the main obstacles facing me. Especially, when I am planning and implementing my lessons by using technological means". This answer was consistent with an answer teacher $(\mathrm{M})$.

Teacher M said, he thought that if time were enough to technology integration in classrooms, the other things would be easy. As he mentions that, was not able to use the technology integration in teaching because of the lack of time. In addition, he said the time was not enough to implement of technology integration in teaching. In addition, he said that due of time constraints: the students could not interact positively with the subject and with their teacher sometimes.

According to teacher R, she said: "the time is important for me, because when the time is available, I can explain the educational material to students". Also, "there is a plenty of time to obtain the best interaction of students with activities in the classroom, which, allows discussing it".

In my opinion, the teachers did not have enough time to technology integration in their teaching. Also, the lack of sufficient time for the planning and implementation of the lectures was the most important obstacles that faced them. Consequently, this effect on the educational goals and reflects negatively on the educational level of students.

\section{Classroom Observations}

The classroom observations showed that the time was an obstacle for all teachers. As a researcher, I observed this thing when I attended as an observer to all teachers in the selected schools.

Through classroom observations, the time has formed an obstacle in front teachers and they are often unable to accomplish the tasks on time. In addition, the classroom timing has been insufficient, so increasing time is important for teachers to prepare and give enough time for the courses. Furthermore, the teachers need to share the curriculum preparation.

Finally, through in my classroom observation I found that the time is the common factor that negatively affects the process of technological integration of all teachers.

\section{DISCUSSION}

The results of this study also revealed that time factor directly influence technological integration in teaching. In addition, the findings of this paper showed that most of the responses indicated that, the time was a major obstacle in front of their technology integration. Furthermore, the classroom observations showed that the time was an obstacle for all teachers. This result similar with result many studies such as: Bauland (2012), Humble-Thaden (2012), Strange (2018), and Winterhalder (2017).

The results of interviews with teachers revealed that the time is a vital factor plays an important role in the continuity of learning and technology integration in teaching. This result agreed with (Beaudry, 2011; Nixon, 2013; Strange, 2018). In addition, it shows that the teacher needs to time for a lesson planning and implementing. Thus, the time is important for the teacher to control teaching process within the classroom. In this study, all teachers have pointed out that the time is a 
major obstacle to them regarding technology integration in their teaching.

In terms of timing, the time allocated forms another problem to some of the topics within the curriculum by observing that in various teachers' classrooms. Furthermore, the teacher has failed to cover the subjects adequately; this confirms the weakness of the curriculum with regard to the time allocated. In the same context, Hew and Brush (2007) urged that teachers need time to preview websites and locate information for lessons. In addition, Kopcha (2010) said that the teachers needing time to plan lessons that integrate technology and time to learn the hardware and software.

As a researcher, I have observed the problem concerned when attending all teachers' classroom in the schools selected. In my opinion, there is a gap lacks to the teaching curriculum, which is the time factor. Therefore, the researcher recommends that policy-makers and stakeholders in the ministry take into their consideration the time factor for planning to teaching. Lastly, the time factor directly influenced technology integration in the classrooms.

\section{LIMITATIONS OF THE STUDY}

A primary limitation of this study was the small sample. Therefore, it might have limitations for this study in terms of generalizability. However, the issue of difficulty in generalising findings from a small sample study.

\section{CONCLUSION AND RECOMMENDATIONS}

\section{Summary}

The aim of this paper is to explore teacher time factor influencing technology integration in Social Studies teaching in this study, the participants were five teachers from five Jordanian schools.

There is a lack of qualitative studies about time factor influencing technology integration in Social Studies teaching in Jordanian schools. This study could provide useful information for teachers on how knowledge and skills influence technology integration in the classroom. Finally, this study will provide guidelines for policymakers in the Jordanian Ministry of Education.

As well as the researcher found, through this study that all answers by the teachers were given unanimously, that the time was one of the most important factors that affected the technology integration in their teaching. Where most of the responses indicated that the time was a major obstacle in front of their technology integration. In most cases, it was the cause of backwardness in the teaching of scientific material. Furthermore, I found out through my classroom observations that the time was an obstacle for all teachers. It was often an obstacle to teachers in the delivery of educational goals and that teachers cannot often accomplish the task on time.

\section{Recommendations}

1. In my opinion, I think that allocation of time for classrooms 45 minutes is not enough to implement technology integration in classrooms. The researcher believes that educational policy makers should increase classroom time from 45 to a full hour to solve timing problem, as well as to help all teachers to integrate technology easier in their teaching.
2. The Ministry of Education should give all teachers free courses on using technological techniques. As I recommend to the Ministry of Education to reduce, the academic overload on the teachers.

3. Policymakers in the ministry and the stakeholders should focus attention on integrating technology in Jordanian classrooms.

4. In conclusion, the researcher believes that the teachers wanting to do the technology integration within the classroom should be well- prepared for the lesson. In addition, all sources and technological tools requirements need to be ready for the implementation of classroom.

\section{RECOMMENDATIONS FOR FUTURE STUDY}

This qualitative study included five social studies teachers in Jordan. This number is small compared to the quantitative studies, which makes generalising the results of the study difficult. Therefore, an urgent need exists for more qualitative research. Nonetheless, more qualitative research should be conducted to understand technology integration in the context of Jordanian classrooms across a variety of subject matter.

\section{REFERENCES}

Abuhmaid, A. (2008). An analysis of ICT integration within the Jordanian education system (Unpublished Doctoral Dissertation). University of Technology, Sydney. Retrieved from https://opus.lib.uts.edu.au/ bitstream/10453/20013/2/02whole.pdf

Agyei, D. D., \& Voogt, J. M. (2011). Exploring the potential of the will, skill, tool model in Ghana: Predicting prospective and practicing teachers' use of technology. Computers \& Education, 56(1), 91-100. https://doi.org/10.1016/j.compedu. 2010.08.017

Al Mulhim, E. (2014). The barriers to the use of ICT in teaching in Saudi Arabia: A review of the literature. Universal Journal of Educational Research, 2(6), 487-493.

Al-Bataineh, M., \& Anderson, S. (2015). Jordanian social studies teachers' perceptions of competency needed for implementing technology in the classroom. Contemporary Educational Technology, 6(1), 38-61. https://doi.org/10.30935/cedtech/6138

Al-Bataineh, M. T. (2014). Jordanian social studies teachers' attitudes and their perceptions of competency needed for implementing technology in their classrooms (Unpublished Doctoral Dissertation). Colorado State University. Retrieved from http://hdl.handle.net/10217/ 80134

Aldhafeeri, F., Palaiologou, I., \& Folorunsho, A. (2016). Integration of digital technologies into play-based pedagogy in Kuwaiti early childhood education: Teachers' views, attitudes and aptitudes. International Journal of Early Years Education, 24(3), 342-360. https://doi.org/10.1080/09669760.2016.1172477

Al-Ghazo, A. (2018). Jordanian EFL students' attitudes toward using World Wide Web net and its' effect on their linguistic proficiency. International Journal of Applied Linguistics and English Literature, 7(2), 82-90. https://doi.org/10.7575/aiac.ijalel.v.7n.2p.82 
Al-Ruz, J., \& Khasawneh, S. (2011). Jordanian pre-service teachers' and technology integration: A human resource development approach, Educational Technology and Society, 1(14), 77-87. Retrieved from https://www.jstor.org/stable/pdf/jeductechsoci. 14.4.77.pdf

Al-Zaidiyeen, N. J., Mei, L. L., \& Fook, F. S. (2010). Teachers' attitudes and levels of technology use in classrooms: The case of Jordan schools. International Education Studies, 3(2), 211-219. https://doi.org/10.5539/ies.v3n2p211

Ames, C. W. (2017). Teacher perceptions of factors influencing technology integration in K-12 Schools (Unpublished Master's Thesis). Utah State University. Retrieved from https://digitalcommons.usu.edu/etd/ 5277

Bandyopadhyay, A. (2013). Technology integration before student outcomes: Factors affecting teacher adoption of technology in India: (Unpublished Doctoral Dissertation). University of Maryland, College Park Retrieved from https://drum.lib.umd.edu/bitstream/handle/ 1903/14067/Bandyopadhyay_umd_0117E_14150.pdf;sequence=1

Bauland, D. (2012). Opinion and practice in a tech-successful elementary school: The 21st century classroom (Masters Dissertations). University of Arizona.

Beaudry, D. (2011). Technology and fifth grade teaching: a study of teacher reported classroom practice, professional development, access, and support. (Doctoral Dissertation). Florida Atlantic University.

Beeson, M. W. (2013). The Influence of Teacher Beliefs and Knowledge on Planning for Technology Integration in Technology-Rich Classrooms (Doctoral Dissertation). The University of North Carolina.

Blackwell, C. K., Lauricella, A. R., \& Wartella, E. (2014). Factors influencing digital technology use in early childhood education. Computers \& Education, 77, 82-90. https://doi.org/10.1016/ j.compedu.2014.04.013

Coleman, L. O., Gibson, P., Cotton, S. R., Howell-Moroney, M., \& Stringer, K. (2016). Integrating computing across the curriculum: The impact of internal barriers and training intensity on computer integration in the elementary school classroom. Journal of Educational Computing Research, 54(2), 275-294. https://doi.org/10.1177/0735633115616645

Creswell, J. W. (2007). Qualitative inquiry and research design: Choosing among five approaches, 16(4), 473-475. https://doi.org/10.1177/1524839915580941

Creswell, J. W. (2009). Research design: Qualitative, quantitative, and mixed methods approach ( $3^{\text {rd }}$ ed.). Los Angeles, CA: SAGE Publications.

Creswell, J. W. (2012). Research design: Qualitative, quantitative, and mixed methods approach ( $4^{\text {th }}$ ed.). Los Angeles, CA: SAGE Publications.

Creswell, J. W. (2014). Research design: Qualitative, quantitative and mixed methods approaches. Thousand Oaks, CA: SAGE Publications.

Hew, K. F., \& Brush, T. (2007). Integrating technology into K-12 teaching and learning: current knowledge gaps and recommendations for future research. Educational Technology Research and Development, 55(3), 223-252. https://doi.org/10.1007/s11423-006-9022-5
Hu, H., \& Garimella, U. (2014). iPads for STEM teachers: A case study on perceived usefulness, perceived proficiency, intention to adopt, and integration in K-12 instruction. Journal of Educational Technology Development and Exchange, 7(1), 49-66. https://doi.org/10.18785/jetde.0701.04

Humble-Thaden, M. B. (2012). Tools for school: Student fluency and perception of cell phones used for learning (Doctoral dissertation). University of North Dakota.

Jordanian Ministry of Education. (2019). Strategic Plan for the Ministry of Education. https://doi.org/10.1155/2018/1935938

Kerckaert, S., Vanderline, R., \& van Brakk, J. (2015). The role of ICT in early childhood education: Scale development and research on ICT use and influencing factors. European Early Childhood Education Research Journal, 23(2), 183-199. https://doi.org/10.1080/ 1350293X.2015.1016804

Kopcha, T. J. (2010). A systems-based approach to technology integration using mentoring and communities of practice. Educational Technology Research and Development, 58, 175-190. https://doi.org/10.1007/s11423-00-9095-4

Lamar, B., Shetia, C., Samms-Brown, C., Iii, B., \& Ulysses, J. (2016). Technology acceptance in a sample of college students. International Journal of Education Research, 11(1),15-26.

Merriam, S. B. (1998). Qualitative research and case study applications in education. San Francisco, CA: Jossey-Bass.

Nixon, T. S. (2013). Mobile devices and the teacher perceived barriers impacting effective integration in the $\mathrm{K}-5$ Classroom (Doctoral Dissertation). University of Phoenix.

Ozdemir, S. (2017). Basic technology competencies, attitude towards computer assisted education and usage of technologies in Turkish lesson: A correlation. International Education Studies, 10(4), 160-171. https://doi.org/10.5539/ies.v10n4p160

Patton, M. Q. (2002). Qualitative interviewing. In Qualitative research and evaluation methods ( $3^{\text {rd }}$ ed., pp. 344-347). Thousand Oaks, CA: SAGE Publications.

Pittman, T., \& Gaines, T. (2015). Technology integration in third, fourth and fifth grade classrooms in a Florida school district. Educational Technology Research and Development, 63(4), 539-554. https://doi.org/10.1007/s11423-015-9391-8

Prestridge, S. (2012). The beliefs behind the teacher that influences their ICT practices. Computers \& education, 58(1), 449-458. https://doi.org/10.1016/j.compedu.2011.08.028

Sekaran, U., \& Bougie, R. (2013) Research methods for business: A skil building approach (6th ed.). West Sussex, UK: John Wiley and Sons.

Shin, W. S. (2015). Teachers' use of technology and its influencing factors in Korean elementary schools. Technology, Pedagogy and Education, 24(4), 461-476. https://doi.org/10.1080/1475939X.2014. 915229

Strange, M. (2018). Exploring K-8 teacher educational technology use: An instrument development study (Unpublished Doctoral Dissertation). Piedmont College. Retrieved from https://media.proquest.com/ media/pq/classic/doc/4327305543/fmt/ai/rep/NPDFz\%BO4iiyIV hw\%2BiouD\%2Ba86kB5aJKg\%3D 
Teo, T., Zhou, M., \& Noyes, J. (2016). Teachers and technology: Development of an extended theory of planned behavior. Educational Technology Research and Development, 64(6), 1033-1052. https://doi.org/10.1007/s11423-016-9446-5

Vatanartiran, S., \& Karadeniz, S. (2015). A needs analysis for technology integration Plan: Challenges and needs of teachers. Contemporary Educational Technology, 6(3), 206-220. https://doi.org/10.30935/ cedtech/6150
Winterhalder, J. E. (2017). Teachers' perceptions and experiences in implementing mobile devices into their teaching (Unpublished Doctoral Dissertation). Walden University. Retrieved from https://scholarworks. waldenu.edu/cgi/viewcontent.cgi? article $=44$ 80\&context $=$ dissertations

Yusop, F. D. (2015). A dataset of factors that influence preservice teachers' intentions to use Web 2.0 technologies in future teaching practices. British Journal of Educational Technology, 46(5), 1075-1080. https://doi.org/10.1111/bjet.12330 